\title{
Is There a Better Way to Study Religion? The View of William E. Paden
}

\author{
Robert A. Segal \\ School of Divinity, History and Philosophy \\ 50-52 College Bounds \\ University of Aberdeen \\ AB24 3DS Aberdeen \\ United Kingdom \\ r.segal@abdn.ac.uk
}

William Paden is known in the profession for two books: Religious Worlds (1988) and Interpreting the Sacred (1992). He has since turned to cognitive, or evolutionary, psychology to explain the origin and development of religion. His latest book, New Patterns for Comparative Religion (2016), is a collection of thirteen previously published essays. The essays overlap with those of the first two books but also venture beyond them, especially in the focus on cognitive psychology. There is also overlap among the essays themselves, as is understandable.

Paden is easy to read. He writes lucidly and even gracefully, although in this latest work he enlists too much jargon. He writes modestly. He does not strut his stuff. He does not pack in excessive notes or references. Above all, his writing is irenic. He takes contrary positions and tries to reconcile them. He is a "both and" rather than "either or" scholar. It is not that he fails to take a stand. It is that the stand he firmly takes is one more of harmony than of conflict.

I want to focus on several topics that Paden discusses throughout this book. He discusses many more, some beyond my ken, but I want to focus on the subjects of: a) evolutionary psychology and functionalism; b) Eliade and Durkheim; and c) old and new comparativism.

\section{Evolutionary Psychology and Functionalism}

Paden rightly distinguishes old-style, nineteenth-century evolution - that of, say, Tylor, Spencer, and Frazer-from the contemporary evolutionism of cognitive psychology (6). Of present-day evolution, he writes: "For instance, what if, for our human species, transmitting 
accounts about the sacred foundations of one's world is itself a natural niche-building behavior for holding one's group together-and thus apiece with survival-fitness?” (7).

To begin with, “survival” was the pet concept of classical evolutionists like Tylor, but by survival they meant mere survival. A survival was simply a relic. Paden means the opposite: he means the continuing usefulness of a custom or a behavior. His notion of survival is Darwinian rather than Tylorian. But then he should make this distinction.

More important, survival for Paden is identical with the movement in the social sciences that opposed and succeeded old-style evolutionism: functionalism, as pioneered by, above all, Malinowski and Radcliffe-Brown in anthropology and Parsons and Davis in sociology. The epitome of functionalism in the study of religion is Rappaport's Pigs for the Ancestors (1968)—a book not mentioned by Paden, who confines himself to the later Rappaport.

Paden confidently touts contemporary evolutionism as new. But he never explains quite how contemporary evolutionism differs at all from functionalism, which itself continues to flourish throughout the social sciences.

\section{Eliade and Durkheim}

Paden most interestingly seeks to bring Eliade and Durkheim, or religious studies and sociology, closer together. The conventional position is that religious studies, or at least the variety that goes back to Müller, Otto, Wach, and Eliade, espouses the existence "out there" of a sacred domain. To be religious is to strive to experience that domain. The starting point for every human, including "archaic,” or "primitive,” man is the profane domain, from which man must escape.

The conventional position is that Durkheim and his followers deny the existence of any sacred realm and instead reduce religion—-better, the gods who are worshiped-to society, or the human group. There is a distinction, as absolute for Durkheimians as for Eliadeans, between the sacred and the profane. But the distinction is wholly on the human level. The sacred means the group; the profane, the individual.

Paden argues that for both Durkheim and Eliade "sacred" and "profane" refer to the way the world is experienced, not to the way the world is. The ontological issue is supposedly sidestepped by both theorists:

Moreover, for each [i.e., Durkheim and Eliade], “world” was not a given, a priori referent but a symbolic schema, a product of the modes through which it is apprehended. That is, a 
world is not an objectivity, but an insider's surroundings, life space, and language, and thus revealed through endless cultural forms. For neither Durkheim nor Eliade do religious worlds tell us the way the world is, but rather they tell us $a$ way the world is ... (38)

On the one hand Eliade himself stresses the experience of space and of time as either sacred or profane: "Our primary concern is to present the specific dimensions of religious experience, to bring out the differences between it and profane experience of the world" (Eliade 1963: 17). On the other hand Eliade stresses the reality of the sacred: "For religious man, this spatial nonhomogeneity [between sacred and profane space] finds expression in the experience of an opposition between space that is sacred - the only real and real-ly-existing space—and all other space ...” (ibid.: 20). True, Eliade may merely be describing and not endorsing the experience of sacred space as real for religious man. So Paden is arguing. But then why, in every word that Eliade writes, does he advocate religion and scorn "seculardom”? If there can as likely exist sheer profaneness as sacredness plus profaneness, why be religious? How can the religious viewpoint for Eliade be other than the way the world actually is?

Ironically, Durkheim himself (1963: 257) repeatedly characterizes religion as real:

But from our point of view, these difficulties disappear. Religion ceases to be an inexplicable hallucination and takes a foothold in reality. In fact, we can say that the believer is not deceived when he believes in the existence of a moral power upon which he depends and from which he receives all that is best in himself: this power exists, it is society.

At the same time Durkheim identifies the sacred with society itself. Analyzing the god of the earliest stage of religion, totemism, he declares that "[t]he god of the clan, the totemic principle, can therefore be nothing else than the clan itself” (ibid.: 236).

Paden asserts that Durkheim uses "sacred” as an adjective, as in "sacred objects," and not as a noun. Therefore Durkheim cannot be charged with reducing the sacred to society. But clearly Durkheim is doing so. To note that Durkheim is concerned with the sacred power that society possesses is still to make society the object of religion. It is society that confers the adjective sacred on anything - on gods, on rituals, on myths, and on persons themselves, who, when they gather, experience themselves as possessed by god, which in fact means by themselves collectively. 
Yet Durkheim no more than Eliade is denying that believers experience the sacred as an independent domain "out there," over and above themselves. He is simply trying to explain that experience. Eliade either is refraining from explaining it, in which case he diverges from Durkheim, or is explaining it as the effect of an encounter with an independent sacred, in which case he is incompatible with Durkheim. Paden's attempt to bring Eliade and Durkheim closer is most commendable, but I just do not see it.

What I also do not see is any consideration of Durkheimian sociology after Durkheim. The neo-functionalism of Jeffrey Alexander and other sociologists would abet Paden's cause. Alexander, breaking with the classical functionalism of Parsons, makes The Elementary Forms of the Religious Life the central neo-functionalist text and accords culture, including religion, far more autonomy. Hence the term for his school: cultural sociology.

Missing even more from Paden’s attempt to make religious studies and sociology more akin is even the mention of Weber. If Paden intends to be discussing the study of religion from the standpoint of social science, why ignore Weber? He would be ideal. True, he is a sociologist and not a religionist. One cannot declare breezily that Weber is already a religionist because of The Protestant Ethic and the Spirit of Capitalism (2001 [1930]). Weber may there be taking on vulgar Marxists, but he is still explaining religion sociologically, not religiously. In his Sociology of Religion (1993 [1920]) the key step in the development of religion is the formation of the group. Undeniably, he is less extreme than Durkheim. For Durkheim, no group, no religion-only magic. For Weber, no group, no advance beyond the first, magical stage of religion, but that stage is still religious and not pre-religious. Without a group, no priests, no prophets, no named gods, no ethics, no metaphysics, no afterlife.

Finally, Paden names a dozen neo-Durkheimians who have influenced the contemporary study of religion: Douglas, Turner, Berger, Dumont, Geertz, Bellah, and LeviStrauss (178). But Berger and Geertz are Weberians, not Durkheimians.

\section{The Comparative Method}

In his two prior books and again in the present one Paden argues for a middle ground between the extremes of what I call "old comparativism” and postmodernism. He insists that both the similarities and the differences among religions be sought. He opposes equally the scorn for differences - the supposed position of old comparativism—and the scorn for similarities - the actual position of postmodernism. Here he is like Jonathan Z. Smith, though mercifully without the bombast and banality (for example, see my criticism of Smith in Segal 2005). 
Let me quote a paragraph that sums up Paden's position:

A new model, rather than taking a lopsided interest in privileging the generic on the one hand (i.e., classical phenomenology), or the ethnographically specific on the other (e.g., anthropology), even-handedly defends the bilateral prospects and character of the comparative process. A new comparative frame will neither ignore resemblances nor simplistically collapse them into superficial sameness - and it will neither ignore differences nor magnify them out of proportion to the human, cross-cultural commonalities of structure and function, which runs through them. In the end, the study of religion becomes an exercise in understanding what recurs, what is different, and why. (103)

Paden's defense of the quest for similarities is admirable. As he puts it, similarities establish connections. He most helpfully offers a list of "universal behaviors," by which he means more than physical actions (110-111). But he wrongly equates recurrent behaviors around the world with universal ones. Similarities need not be found everywhere and can even be found in-yes-just one place.

More, similarity is not essence. The term “essentialism,” invoked repeatedly, is misused, not just by Paden but by seemingly everyone else in religious studies as well. Essence is a metaphysical concept. The essence of water is H20. But the essence of religion is more or even other than the sacred or society. Essence does not mean most important or key. Defining religion as the belief in god is not giving its essence. Debates going back to Tylor and Durkheim are over the definition, not the essence, of religion. Theories of religion offer necessary, sufficient, or both necessary and sufficient conditions for religion, but those conditions fall short of the essence of religion. Even purportedly outright universal characteristics of religion are merely empirical claims that do not bear on the essence of religion.

Paden declares that the study of religion must seek at once similarities and differences. While he refreshingly spurns postmodernists, who seek only differences, he never justifies his quest for differences as well as similarities. Does natural science seek differences? Why should religious studies? Why is sameness ever "superficial”? And why is difference not always trivial?

Paden names anthropology as a case of particularism. But it is not. Undeniably, the heart of anthropology since Malinowski has been fieldwork, which by nature focuses on the specifics of the culture studied first-hand. But Malinowski himself generalizes from the 
Trobriand Islanders to humanity altogether. Geertz, celebrated as a budding postmodernist, depends on universal or near-universal categories, such as marriage, to discover differences. Indeed, differences start only where similarities end. Similarities underlie differences. How else does Geertz manage to distinguish Morocco from Indonesia?

The epitome of what I call old comparativism is J. G. Frazer, whom Paden never mentions. Frazer definitely seeks only similarities among religions worldwide. But finding similarities, let alone finding patterns for those similarities, is a feat. Finding differences is easy. To invoke a famous distinction between physics and everything else, it is like stamp collecting. Yet Frazer never denies differences, as postmodernists would assume. He does not confuse similarity with identity. Frazer is just not interested in differences. Why should he be? Paden, while not spurning similarities, never says why.

Paden touts his “new comparativism” as new. But William Robertson Smith, who is cited, practiced this middle ground even before Frazer, who dedicates The Golden Bough (first edition 1890) to him. In most of all his culminating Lectures on the Religion of the Semites (first edition 1889), Smith seeks to show that Christianity and, leading to it, Judaism were at once primitive and modern (see Segal 2002). Smith strives to show how prophetic Israelite religion and then early Christianity broke with their own primitive roots. Smith was castigated for daring to find both similarities and differences. Just what does new comparativism add?

Paden's knowledge of the history of the comparative method is limited. He seems unfamiliar with the scores of classic writings on the method (for example, Segal 2001). More deeply, he disregards the relationship between similarities and science on the one hand and differences and the humanities on the other. Why does science seek only similarities, and why typically do the humanities seek only differences? (A field like comparative literature is separate from French or English exactly because it is comparative.) The key difference between explanatory and interpretive social science - the issue raised by Geertz-is exactly that between the stress on similarities and the stress on differences. Paden emphasizes that evolutionary psychology is scientific, but then how does he reconcile that approach with his new comparativist emphasis on differences as well? The issue is ultimately philosophical.

Above all, why must the study of religion be both scientific and humanistic? Why can it not be either? Paden never explains why the quest for both similarities and differences is superior to the quest for either one alone. Neither of the opposing sides denies the existence, only the importance, of the other. To seek similarities is simply to assume that they are more significant than differences. To seek differences is simply to assume that they are more 
significant than similarities. But on what grounds other than question-begging ones does the vaunted superiority of either side rest?

Overall, Paden's book is a most helpful consideration of some of the central issues in the study of religion. It merits much praise. But it needs, I think, to go further.

\section{References}

Durkheim, Emile. (1963 [1915]). The Elementary Forms of the Religious Life. Translated by Joseph Ward Swain. Glencoe, IL: Free Press.

Eliade, Mircea. (1963). The Sacred and the Profane. Translated by Willard R. Trask. New York: Harcourt Brace.

Paden, William E. (1988). Religious Worlds: The Comparative Study of Religion. Boston, MA: Beacon Press.

- (1992). Interpreting the Sacred: Ways of Viewing Religion. Boston, MA: Beacon Press.

Rappaport, Roy A. (1968). Pigs for the Ancestors: Rituals in the Ecology of a New Guinea People. New Haven, CT: Yale University Press.

Segal, Robert A. (2005). Classification and comparison in the study of religion: The work of Jonathan Z. Smith. Journal of the American Academy of Religion 73: 1175-1188.

- (2002). Introduction. In William Robertson Smith, Religion of the Semites, vii-xlii. Piscataway, NJ: Transaction.

- (2001). In defense of the comparative method. Numen 48: 339-373.

Weber, Max. (2001 [1930]). The Protestant Ethic and the Spirit of Capitalism. Translated by Talcott Parsons. London and New York: Routledge.

- (1993 [1920]). The Sociology of Religion. Translated by Ephraim Fischoff. Boston, MA: Beacon Press. 